\title{
Peningkatan Pengetahuan Ibu tentang Pentingnya Imunisasi Dasar pada Bayi Usia 0 s/d 1 Tahun di Wilayah Kerja Puskesmas Mandiangin Kota Bukittinggi
}

\author{
Media Fitri*1, Yellyta Ulsafitri² $^{2}$, Sri Oktavia ${ }^{3}$ \\ 1,2,3Diploma Tiga Kebidanan, STIKes Yarsi Sumbar Bukittinggi, Indonesia \\ *e-mail: mediafitri09@gmail.com ${ }^{1}$,yellytaulsafitri28@gmail.com ${ }^{2}{ }_{\text {srioktavia151@gmail.com }}^{3}$
}

\begin{abstract}
Abstrak
Imunisasi adalah suatu upaya untuk meningkatkan kekebalan seseorang secara aktif terhadap suatu penyakit, sehingga jika terpapar dengan penyakit tersebut tidak akan sakit atau hanya saja mengalami gejala ringan. Di wilayah kerja Puskesmas Mandiangin Kota Bukittinggi ini, cakupan imunisasi dasar pada bayi 0 sampai dengan 1 tahun masih dalam kategori rendah (87\%). Masih rendahnya cakupan imunisasi di wilayah kerja puskesmas mandiangin ini dikarenakan kurangnya pengetahuan ibu tentang imunisasi dasar dan perkembangan mitos-mitos yang tidak baik tentang imunisai pada bayi usia 0 sampai dengan 1 tahun sehingga sebagian besar ibu tidak mau membawa anaknya ke Puskesmas untuk melakukan imunisasi. Pengetahuan ibu terhadap imunisasi merupakan faktor yang sangat penting agar ibu dapat cepat tanggap dan tahu apa yang harus dilakukan ketika timbul efek samping pada anaknya. Berdasarkan masih rendahnya cakupan imunisasi dasar pada bayi usia 0 sampai dengan1 tahun, maka dilakukan koordinasi dengan bidan beserta kader di wilayah kerja puskesmas mandiangin untuk mendata ibu-ibu yang memiliki bayi untuk menetapkan jadwal melaksanakan penyuluhan. Kegiatan pengabdian masyarakat ini dilakukan dengan metode penyuluhan dan memperagakan kepada ibu secara langsung apa-apa saja jenis imunisasi dasar pada bayi usia 0 sampai dengan 1 tahun beserta efek samping yang akan ditimbulkan. Penyuluhan dilakukan oleh tim pengabdian masyarakat dibantu bidan dan kader di wilayah kerja Puskesmas Mandiangin Kota Bukittinggi. Kegiatan PKM ini sangat memberikan manfaat kepada masyarakat yaitu masyarakat mengetahui secara jelas imunisasi dasar pada bayi dan cara penanganan awal efek samping imunisasi dasar ini. Sehingga masyarakat dapat menepis mitos-mitos yang beredar mengenai imunisasi ini.
\end{abstract}

Kata kunci: Bayi Usia 0 s/d 1 Tahun, Dasar, Imunisasi

\begin{abstract}
Immunization is an effort to actively increase a person's immunity to a disease, so that if exposed to the disease, you will not get sick or only experience mild symptoms. In the work area of the Mandiangin Public Health Center, Bukittinggi City, the coverage of basic immunization for infants 0 to 1 year is still in the low category (87\%). The low immunization coverage in the work area of the Mandiangin Public Health Center is due to the lack of knowledge of mothers about basic immunization and the development of bad myths about immunization in infants aged 0 to 1 year so that most mothers do not want to take their children to the Puskesmas for immunization. Mother's knowledge of immunization is a very important factor so that mothers can respond quickly and know what to do when side effects arise in their children. Based on the low coverage of basic immunization for infants aged 0 to 1 year, coordination was carried out with midwives and cadres in the work area of the Mandiangin Health Center to collect data on mothers who have babies to determine a schedule for conducting counseling. This community service activity is carried out with the method of counseling and demonstrating directly to mothers what types of basic immunization are for infants aged 0 to 1 year and the side effects that will be caused. The counseling was carried out by the community service team assisted by midwives and cadres in the work area of the Mandiangin Public Health Center, Bukittinggi City. This PKM activity is very beneficial to the community, namely that the community clearly knows basic immunization for infants and how to early handling the side effects of this basic immunization. So that people can dispel the myths circulating about this immunization.
\end{abstract}

Keywords: Basic, Infants Age 0 to 1 Years, Immunization

\section{PENDAHULUAN}

Imunisasi adalah suatu upaya untuk menimbulkan/meningkatkan kekebalan seseorang secara aktif terhadap suatu penyakit, sehingga bila suatu saat terpapar dengan penyakit tersebut 
tidak akan sakit atau hanya mengalami sakit ringan (Dwienda $R, d k k, 2014$ ). Setiap tahun lebih dari 1,4 juta anak di dunia meninggal karena berbagai penyakit sebenarnya dapat dicegah dengan imunisasi. Beberapa penyakit menular yang termasuk ke dalam Penyakit yang dapat dicegah dengan Imunisasi (PD3I) antara lain TBC, Difteri, tetanus, Hepatitis B, Pertusis, Campak, Polio, Radang selaput otak dan radang paru-paru. Anak yang telah diberi imunisasi akan terlindungi dari berbagai penyakit berbahaya tersebut, yang dapat menimbulkan kecacatan atau kematian (Kemenkes RI, 2016).

Berdasarkan data dari Wilayah Kerja Puskesmas Mandiangin bahwa masih belum tercapainya cakupan bayi usia 0 sampai dengan 1 tahun melaksanakan imuniasi dasar yaitu 87\% (Dinkes Bukittinggi, 2019). Sehingga tenaga kesehatan yang bertanggungjawab untuk mencapai target pencapaian imunisasi harus melakukan berbagai upaya dalam peningkatan capaian imuniasasi ini. Hasil observasi tim pengabdian diketahui beberapa permasalahan yang teridentifikasi sehingga dirasa penting dilakukan penyuluhan dalam upaya peningkatan pengetahuan ibu tentang imunisasi dasar pada bayi ini. Selain itu, mitos-mitos yang berkembang di masyarakat bahwa imunisasi bisa menyebabkan berbagai penyakit dan kelumpuhan pada bayi yang telah diimunisasi. Masih rendahnya cakupan imunisasi di Wilayah Kerja Puskesmas Mandiangin ini dikarenakan kurangnya antusias masyarakat pada saat kader-kader mensosialisasikan dan menghimbau masyarakat untuk membawa bayinya ke Posyandu untuk di lakukan imunisasi. Faktor lain yang menyebabkan kurangnya antusias masyarakat adalah faktor kesibukan pekerjaan sehari-hari dan faktor anak yang tidak bisa ditinggal pada saat ibu datang ke Posyandu. Oleh karena itu, kami tim pengabdian masyarakat melaksanakan penyuluhan ini dengan memastikan ke masyarakat kapan jadwal yang tepat untuk melaksanakan penyuluhan dan sosialisasi ini. Penyuluhan dan sosialisasi ini kami bagi dalam beberapa kelompok kecil yang terdiri dari 6-7 orang sesuai jarak-jarak rumah masyarakat sehingga semua masyarakat dapat mengikuti penyuluhan ini.

Pemberian imunisasi melalui penyuluhan atau pendidikan kesehatan tentang imunisasi merupakan upaya promotif untuk meningkatkan pengetahuan tentang imunisasi dan preventif untuk pencegahan penyakit, sehingga mampu menumbuhkan kesadaran orangtua membawa anaknya ke Posyandu untuk mendapatkan imunisasi dasar secara lengkap. Oleh karena itu, Pengabdian Kepada Masyarakat sangat penting dilakukan sehingga tercapainya target cakupan imunisasi di Wilayah Kerja Puskesmas Mandiangin.

\section{METODE}

Kegiatan Pengabdian Kepada Masyarakat ini dilakukan dengan beberapa tahap. Pada tahap awal dilakukan identifikasi masalah yang ada di Wilayah Kerja Puskesmas Mandiangin Kota Bukittinggi. Kemudian dilaksanakan rencana dan tahap pelaksanaan kegiatan. Adapun rincian kegiatan pengabdian kepada masyarakat ini adalah:

1) Survei ke lokasi Wilayah Kerja Puskesmas Mandiangin Kota Bukittinggi berkoordinasi dengan kader-kader dan bidan penanggung jawab di Wilayah Kerja tersebut.

2) Setelah mendapatkan data, tim pengabdian kepada masyarakat melakukan wawancara dengan beberapa masyarakat kendala untuk datang ke Posyandu dan alasan mengapa bayinya tidak dibawa imunisasi.

3) Merencanakan kegiatan pengabdian kepada masyarakat dalam upaya peningkatan pengetahuan ibu tentang imunisasi dasar pada bayi.

4) Sosialisasi dengan menggunakan leaflet, gambar dan memperagakan jenis vaksin yang akan di imunisasikan ke bayi tersebut.

Dalam rangkaian kegiatan pengabdian kepada masyarakat ini metode yang dilaksanakan antara lain:

a. Metode ceramah dipilih untuk menyampaikan konsep imunisasi dasar pada bayi, tujuan dilakukan imunisasi, jadwal pemberian imunisasi, efek samping yang ditimbulkan, dan penanganan awal mengatasi efek samping imunisasi. 
b. Mendemontrasikan dengan menggunakan leaflet, gambar beserta vaksin imunisasi langsung kepada masyarakat sehingga masyarakat dapat mengetahui langsung jenis imunisasi apa yang diberikan ke anaknya.

c. Membagikan leaflet kepada masyarakat sebagai bahan bacaan dirumah serta dijadikan referensi bagi ibu-ibu hamil muda guna persiapan untuk kelahiran bayi mereka.

Setelah pelaksanaan penyuluhan selesai, tim pengabdian masyarakat melakukan observasi untuk mengetahui hasil/dampak setelah pelaksanaan kegiatan. Dampak dari hasil penyuluhan ini adalah masyarakat mau membawa anak-anak mereka untuk imunisasi di Posyandu. Namun bagi masyarakat yang tidak bisa ke Posyandu, mereka mau menerima tenaga kesehatan/bidan mendatangi rumah mereka secara door to door untuk melakukan imunisasi. Selain itu, berdampak pada keyakinan masyarakat yang tidak benar mengenai mitos-mitos tentang imunisasi ini.

\section{HASIL DAN PEMBAHASAN}

\subsection{Survei Pendahuluan dan Persiapan Materi Kegiatan}

Survei pendahuluan dilaksanakan pada Selasa tanggal 8 Juni 2021 di Puskesmas Mandiangin Kota Bukittinggi. Survey tersebut bertujuan untuk memohon ijin dan menanyakan permasalahan yang belum teratasi tentang bayi dan balita. Kepala Puskesmas dengan tim pengabdian kepada masyarakat menyepakati untuk melakukan pengabdian kepada masyarakat tentang masalah bayi dan balita yang belum teratasi dan disepakati jadwal pelaksanaannya. Secara garis besar telah dijelaskan tahapan yang akan dilaksanakan yakni penyuluhan kepada masyarakat secara kelompok kecil yang dibagi-bagi dengan tim pengabmas dan mendemontrasikan jenis-jenis vaksin yang akan diimunisasikan ke bayi.

\subsection{Penyuluhan Pentingnya Imunisasi Dasar Pada Bayi}

Kegiatan penyuluhan dilaksanakan selama 1 hari yaitu tanggal 23 Juni 2021 dengan melibatkan kader-kader posyandu, bidan yang bertanggung jawab di wilayah kerja Puskesmas Mandiangin Kota Bukittinggi. Tujuan kolaborasi ini adalah pertama untuk menyebarluaskan informasi untuk imunisasi dan penyuluhan pentingnya imunisasi dan kedua untuk menjajaki ibu-ibu yang mempunyai bayi usia 0 sampai 1 tahun yang belum melakukan imuniasi. Selanjutnya kegiatan awal dilakukan penyuluhan tentang pentingnya imunisasi bayi usia 0 sampai dengan 1 tahun kepada ibu-ibu sasaran dan menanyakan kepada ibu-ibu apa yang menjadi kendala selama ini untuk tidak bisa melaksanakan imunisasi seperti mitos-mitos imuniasi yang tersebar di masyarakat.

Dari hasil wawancara dengan masyarakat didapatkan hasil bahwa ibu terkendala waktu ataupun terkendala jarak ibu ke Posyandu ataupun ke Puskesmas serta terkendala anak yang tidak bisa ditinggalkan di rumah. Selain itu ada beberapa masyarakat mempunyai pemikiran dan mendapatkan informasi bahwa imunisasi dapat menyebabkan kelumpuhan pada bayi setelah imunisasi. Mitos ini sebenarnya sudah lama berkembang di masyarakat setempat. Oleh karena dasar seperti itu, tim pengabdian masyarakat memberikan penyuluhan kelompok kecil dengan jarak rumah ibu yang dekat sehingga semua masyarakat khususnya ibu yang mempunyai bayi mengetahui pentingnya imunisasi ini diberikan dan menjelaskan kebenaran informasi mengenai imunisasi ini.

Penyuluhan dibagi menjadi kelompok-kelompok kecil, masing-masing terdiri dari 6-7 orang perkelompok. Masing-masing kelompok diberikan materi oleh tim pengabmas, bidan, dan dibantu oleh mahasiswa. Materi yang disampaikan adalah mengenai konsep imunisasi, jenisjenis imunisasi, tujuan dilaksanakan imunisasi, jadwal pemberian imunisasi, efek samping imunisasi serta penanganan awal jika terjadi kejadian ikutan pasca imunisasi (KIPI).

Kegiatan penyuluhan bisa terlihat pada Gambar 1. 

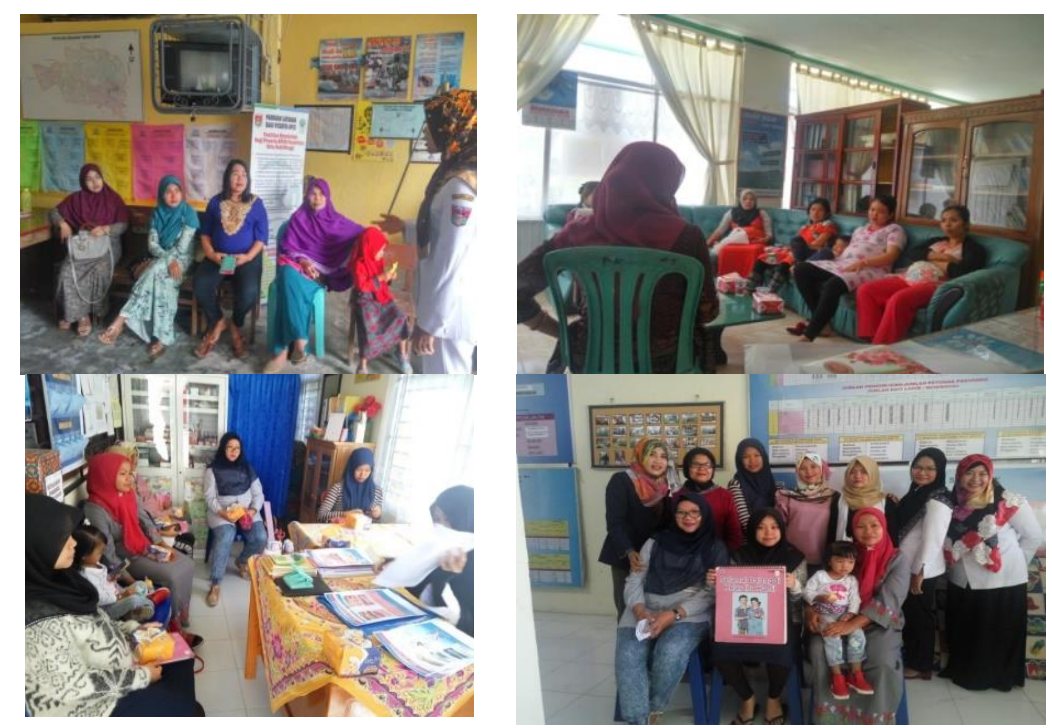

Gambar 1. Kegiatan Penyuluhan

Pada saat penyuluhan dan sosialisasi ini diberikan kesempatan seluas-luasnya kepada masyarakat untuk bertanya tentang topik yang dijelaskan. Ceramah dan diskusi berjalan dengan lancer. Beberapa masyarakat yang ikut dalam penyuluhan menanyakan tentang efek samping yang terjadi setelah dilakukan imunisasi karena ada beberapa ibu berpengalaman setelah dilakukan imunisasi, anak mereka mengalami demam dan ibu merasa panic. Tim pengabmas mengarahkan dan menjelaskan apa langkah-langkah yang harus dilakukan ibu ketika timbul demam setelah imunisasi ini.

Diakhir sesi penyuluhan dan sosialisasi, tim pengabmas membagikan leaflet kepada ibu sebagai bahan bacaan untuk pemberian imunisasi berikutnya.

\section{KESIMPULAN}

Peningkatan pengetahuan ibu tentang pentingnya imunisasi dasar pada bayi usia 0 sampai 1 tahun diharapkan dapat meningkatkan kesadaran orangtua khususnya ibu untuk membawa anaknya ke Posyandu untuk melakukan imunisasi sesuai jadwal dan usia bayi ibu tersebut.

\section{UCAPAN TERIMA KASIH}

Ucapan terima kasih kami sampaikan kepada Sekolah Tinggi Ilmu Kesehatan Yarsi Kota Bukittinggi yang telah membiayai kegiatan penyuluhan ini serta kepada kader, bidan yang telah berkolaborasi dan membantu kami dalam kegiatan pengabdian kepada masyarakat ini. Penulis juga mengucapkan terima kasih kepada Puskesmas Mandiangin Kota Bukittinggi yang telah memfasilitasi dan membantu kegiatan ini.

\section{DAFTAR PUSTAKA}

Dinas Kesehatan Kota Bukittinggi. (2019). Profil Kesehatan Kota Bukittinggi Tahun 2019. Bukittinggi: Dinas Kesehatan Kota Bukittinggi.

Dwienda R, dkk. (2014). Buku Ajar Asuhan Kebidanan Neonatus, Bayi dan Balita. Yogyakarta, Depublish.

Hartati, I. (2019). Faktor-faktor yang mempengaruhi status imunisasi dasar lengkap pada bayi usia 0-12 bulan di desa Suka Mulia Kecamatan Rantau Kabupaten Aceh Tamiang. JP2K, 2(1), 41-53. Diakses tanggal 8 Juni 2021. 
Kementrian Kesehatan Republik Indonesia (2016). Kemenkes RI Tahun 2016, Jakarta

Marimbi, H. (2010). Tumbuh kembang, status gizi dan imunisasi pada balita. Yogyakarta: Nuha Medika.

Ritongga, M.RS. (2014). Hubungan antara dukungan keluarga terhadap kepatuhan ibu melaksanakan imunisasi dasar pada anak di Desa Tigabolon Kecamatan Sidamanik Kabupaten Sidamulun. Universitas Sumatera Utara, Medan. 


\section{Halaman Ini Dikosongkan}

